\title{
EMPOWERMENT OF HOSPITAL SANITATION WORKERS AS A MEDIA FOR TRANSFERRING COVID-19 PREVENTION KNOWLEDGE TO THEIR FAMILIES
}

\author{
Masfiyah, Rahayu \\ Department of Clinical Microbiology, Faculty of Medicine, \\ Universitas Islam Sultan Agung - Sultan Agung Islamic Teaching Hospital
}

\begin{abstract}
Background: From the outset of the Coronavirus disease 2019 (COVID-19) pandemic, it was clear that hospitals were an important setting for viral transmission. Hospital sanitation workers are high-risk group of exposure to COVID-19, which may lead to transmission of people whom they interact, especially their families. This study aimed to describe the percentage of knowledge transferred to families of hospital sanitation workers after receiving the COVID-19 transmission prevention training.

Subjects and Method: This was a cross-sectional study conducted at Islam Sultan Agung Hospital, Semarang, Central Java, from September to December 2020. The study subjects were (1) 25 hospital sanitation workers who received COVID-19 transmission prevention training; and (2) 25 family members of those hospital sanitation workers who answered the same questions of the conducted training. The variables of the COVID-19 transmission prevention training were the practice of personal protective equipment, disinfectants, environmental hygiene, cough etiquette, and hand washing practices. The data of transferred knowledge were collected using questionnaire answered by the family member and described in percent.

Results: Most of the family members of hospital sanitation workers were female (68\%), high school level of education (83.3\%), and self-employed or housewives (96\%). From the score of knowledge gained from $0-100$, the subject family members scored the knowledge about the practice of personal protective equipment (score $=100$ ), environmental hygiene (score $=70$ to 100 ), disinfectants (score $=84$ to 100), cough etiquette (score $=76$ to 100), and hand washing ( 80 to 100). As many as $72 \%$ family members of hospital sanitation workers was transferred knowledge about COVID-19 transmission prevention.
\end{abstract}

Conclusion: Hospital sanitation workers transfer the COVID-19 transmission prevention knowledge to their family members.

Keywords: COVID-19 transmission prevention, knowledge, ospital sanitation workers

\section{Correspondence:}

Masfiyah. Department of Clinical Microbiology, Faculty of Medicine, Universitas Islam Sultan Agung-Islam Sultan Agung Hospital. Jl Kaligawe Km 4 Semarang, Central Java. Email: masfiyah@unissula.ac.id. Mobile: 081901187887. 